\title{
A GIS-BASED MAPPING AND ESTIMATION THE CURRENT FOREST LANDSCAPE STATE AND DYNAMICS
}

\author{
VERA RYZHKOVA, IRINA DANILOVA, MIKHAIL KORETS \\ GIS Laboratory, V.N. Sukachev Institute of Forest, Siberian Br., Russian Academy of \\ Sciences, 50/28, Akademgorodok, Krasnoyarsk 660036, Russia, email:vera@ksc.krasn.ru
}

Received: $30^{\text {th }}$ August 2010, Accepted: $19^{\text {th }}$ May 2011

\begin{abstract}
Classification and inventory of the current diversity of forest communities and their environments (i.e. site conditions) were developed based on Kolesnikov's topogenetic classification approach in Angara region (Central Siberia). This classification considers characteristics of forest regeneration dynamics, such as trends and rates of forest regeneration succession in a range of site conditions; therefore, it is used as a basis of a key for a forest regeneration dynamics map. An algorithm of forest regeneration dynamics mapping based on a spatial analysis of multi-band satellite data, a digital elevation model (DEM), and ground data combined with expert estimates of the resulting land cover classes was applied using geographic information system (GIS) "Forests of Central Siberia". Based on this algorithm, Landsat 7 ETM+ satellite imagery, SRTM-3- DEM, and field data were processed for the Angara test site. The resulting maps include two polygonal vector layers: one is forest regeneration stages (stand types) and the other is forest succession series (forest types) in a range of site conditions.
\end{abstract}

Keywords: Central Siberia, regeneration succession, site conditions, forest type, stand type, forest regeneration dynamics map, GIS, digital elevation model (DEM), remote sensing data

\section{INTRODUCTION}

Siberian boreal forests, a unique biome of forest ecosystems situated along the northern tree line of Asia, perform globally important environmental functions. Siberian forests, as compared to European forests, still cover vast areas and are characterized by natural dynamics. They can be considered as a reference of species and ecosystem diversity. Monitoring of forest ecosystem biodiversity and sustainability under ever increasing human-caused environmental stresses is a major forest protection challenge.

Classification and mapping of forest communities are among research priorities nowadays, because vegetation cover of Siberia has changed drastically over the past fifty years as a result of logging, fire, insect outbreaks, increasing industrial emissions, and natural disasters. Forest cover mapping is a basic component of forest monitoring systems that enables spatial interpretation and estimation of current changes of forest state and dynamics caused by various factors. 
Maps created using traditional methods become out of date very soon. At present, creating new or updating old maps involves the use of satellite images and GIS technologies in combination with traditional mapping methods. A major weakness of traditional map creation is a strong influence of a human factor on delineation of objects of interest (Konovalova et al. 2005; Mkrtchan 2006). With GIS technologies, this human influence is minimized, since using these technologies enables development of methods to identify land cover units, such as forest cover, having similar pre-set characteristics. Use of GIS technologies, the most effective tool to analyze and classify spatial information, has improved our understanding of forest cover dynamics immensely. A map is no longer a static picture; it is a regularly updated computer database.

Increasing aerial and satellite information used in building and updating GIS-based thematic maps, as well as a growing need for its high accuracy and rate of interpretation necessitate automation of satellite data processing and thematic mapping procedures. Approaches to GIS-based mapping of hierarchical ranks of land cover units using robust information processing algorithms are discussed in a number of papers published over the past several years (Konovalova et al. 2005; Sysuev 2006; Ermakov et al. 2007). These approaches cover baseline field data collection and processing, remote sensing data interpretation, and automated development of thematic maps. The resulting land cover units vary in thematic characteristics, size, and hierarchical rank.

Most studies addressing DEM-based thematic map development deal with landscape mapping. Landscape units (which are land cover units) are identified using automated classification of DEM (Mkrtchan 2006) and satellite imagery (Puzachenko et al. 2003; Konovalova et al. 2005) or by their spatial analysis (Merekalova 2006). Noteworthy is a method of determination of potential topography-controlled site conditions type based on detailed analysis of DEM morphometric characteristics proposed by Sysuev and Shary (2000).

Another research direction is recognition of vegetation cover units of different ranks (Ermakov et al. 2007), vegetation cover classes and dominant woody species (Kharuk et al. 2005) in space images, characteristics reflected in DEM being used as indirect descriptors of vegetation site conditions. Morphometric relief parameters (Sysuev and Shary 2000) or DEM-based calculated complex ecological characteristics (Mkrtchan 2006) are used for automated DEM classification.

Automated mapping of vegetation cover, particularly its regeneration dynamics, is a challenging problem covering a number of tasks which can be accomplished only through interdisciplinary research efforts. One of these tasks is recognition of forest types in space images. Although development of approaches to forest type recognition in aircraft images has a history of almost fifty years (Kireyev 1963), no universal method has been proposed. It is hard to develop universal methods, on the one hand, because of a great variety and complex arrangement of forest communities. On the other hand, the number of forest type characteristics reflected in aerial and satellite images are less than that covered by the traditional forest type definition (Sukachev 1972). For example, woody species is a direct forest type feature, but stand species composition can only be recognized in detailed-scaled aerial images, whereas multispectral images do not cover the entire diversity of forest types and site conditions. This reduces effectiveness of using aerial and space images for forest type determination. To identify forest types, indirect features are used, such as relief elements indicating certain forest site conditions. GIS technologies are the most promising tool regarding automated recognition of forest site conditions that largely control vegetation structure and species composition. 
Computer programs available nowadays to process remote sensing data (RSD), as well as increasing space imagery resolution allowed to automate traditional methods of RSD analysis to a fairly high level and to combine them as a single technology. Use of this technology facilitates RSD analysis and provides higher confidence and detail of its results.

Another task is to choose classification criteria that could take into account forest regeneration dynamics characteristics, as scientific and practical value of any thematic map is largely determined by principles of classification of the objects of interest. These principles are based upon in developing map keys. Therefore, vegetation communities and their dynamic states should be classified so that their spatial distribution, as well as their origin and future development trends is reflected.

Continuously increasing anthropogenic impacts on the environment have resulted in a sharp decrease in areas occupied by native undisturbed ecosystems. Many ecosystems have been disturbed and shifted from climax to succession over the past 50 years. Fire disturbs up to ten million hectares of taiga forests every year.

Therefore, our two-prong study focused on classification and inventory of the existing diversity of forest ecosystems as a basis of estimation of the current state and trends of forest succession for a range of site condition and development of an algorithm of computer mapping of forest ecosystem regeneration dynamics. This algorithm should be based on automated methods of spatial data analysis combined with expert data estimates.

\section{Study area}

This study was conducted in Angara region $\left(57^{\circ}-59^{\circ} 00^{\prime} \mathrm{N}, 99^{\circ}-103^{\circ} 00^{\prime} \mathrm{E}\right)$, the southernmost geographical province of the central Siberian geographical area found within the Central Siberian Plateau. The study area is an elevated plain gently sloping northeastward and having both plain and mountain topographical characteristics. Angara folds and multiple trap outcrops occur in this generally plain area. The surface structure non-uniformity accounts for diverse forest vegetation in this area. The study area is located on the Angara trap plateau elevated 300-500 m above sea level (a.s.1.).

The area is in extremely continental climate, climate continentality increasing westeastward. Average annual air temperature is $-2.1^{\circ} \mathrm{C}$ to $-2.4^{\circ} \mathrm{C}$, amplitude of average monthly temperatures is about $40-43^{\circ} \mathrm{C}$. Annual precipitation is $320-490 \mathrm{~mm}$ and decreases northeast-southwestward. Winter precipitation (100-160 mm) accounting for $25-35 \%$ of the total annual precipitation received by this area and is sufficient to form $35-70 \mathrm{~cm}$ deep snow cover (Popov 1982). Permafrost occurs as "islands" and covers $20-30 \%$ of the total area.

Forest vegetation characteristics change considerably with elevation, particularly in the mountain-like parts of the area. However, elevation-caused vegetation changes are also observed in the elevated plain parts. The lower altitudinal belt of light (i.e. light-needled) conifer forest (Pinus sylvestris L., Larix sibirica Ledeb.) and upper belt of dark (i.e. darkneedled) conifer forest (Picea obovata Ledeb., Abies sibirica Ledeb., Pinus sibirica Du Tour) are found across the study area (Popov 1982).

Elevated watersheds (over 600m a.s.1.) located on the Angara folds are covered by Siberian pine stands, whereas dark conifers occur as low as $400 \mathrm{~m}$ a.s.l. Scots pine stands are widely spread in lower water, mixed Scots pine/larch stands occupying watershed slopes. Spruce forest covers small river valleys. Secondary birch stands accounting for 10$15 \%$ of the total forest area are initial post-fire or post-harvesting stages of Scots pine, larch, and spruce forest regeneration (Popov 1982). 
Analyzing genesis of and classifying Angara forests is a complicated task, as these forests are heavily disturbed by fire and are, hence, represented by different post-fire vegetation regeneration stages.

\section{MATERIALS AND METHODS}

Classification of forest communities taking into account their regeneration dynamics was done using a topogenetic approach developed by Ivashkevich (1933) and Kolesnikov (1956) for mountain forests of the Russian Far East. A topogenetic (from Greek genesis origin, i.e. based on origin in similar topographic conditions) approach allows to build forest classification that reflect forest community regeneration in various environmental (site) conditions.

This approach has since then been improved and used in several regions of Russia varying in forest site conditions, such as the Urals (Smolonogov 1970, 1998; Zubaryeva et al. 1983), Caucasus (Golgofskaya 1983), south of central Siberia (Krauklis and Medvedev 1966; Popov 1982), and the Russian Far East (Rosenberg and Manko 1983). Classification principles similar to those behind the Russian topogenetic approach were also used by researchers from other countries (Pfister et al. 1977; Walker 2000).

According to this approach forest ecosystem diversity is created by forest development or regeneration stages present at the same time in a given area. The major unit of the topogenetic classification of forest cover is forest type which is interpreted as a series of genetically linked successive vegetation communities developing under certain type of a forest site conditions. Type of forest site conditions is identified based on geological and geomorphological structure of any given area. The topogenetic approach to classification of forest vegetation is based on a concept that all stands found within an area relatively uniform in geographic location and topography are of a common origin, i.e. they are considered as the age stages of the major-woody-species stand for certain forest site conditions. Secondary and major woody stands (stand types) occurring in a certain type of forest site conditions are grouped to make a major vegetation regeneration series. This series is called a forest type.

This topogenetic approach considerably increases possibilities to map vegetation cover dynamics using GIS. With this approach, diversity of forest communities is classified based on similarity of forest site conditions. As a result of DEM analysis, sites similar in topographic location, combination of relief elements, and, hence, in ecological regimes controlling vegetation are identified in the area of interest.

We used this approach for classifying forests of central Angara region, which are heavily disturbed by fire and logging and are currently represented by various stages of the major woody species regeneration. High diversity of these regeneration stages makes it hard to identify natural genesis of these forests and to classify them. To classify these forests, we used systems of forest cover units developed for forests of the Ural mountains (Kirsanov and Smolonogov 1967; Filroseh 1983) and elevated plain of south central Siberia (Popov 1982). This approach was chosen based on the study area similarity in geographical conditions to the territories described by the authors above (low mountains and elevated plains), as well as its likeness to their classification approach which considers the forest ecosystem diversity as an aggregate of forest regeneration stages in different site conditions.

GIS "Forests of Central Siberia" (Cherkashin and Korets 2004) and subsystem "Forest Dynamics and Diversity" (Ryzhkova et al. 2004) were used to develop an algorithm of 
automated mapping of forest regeneration dynamics. The GIS basic information layers, such as a topographic base map, a raster-vector relief model, aerial and satellite imagery, general geographic and thematic maps, and a database of ground observations conducted on sample sites, were incorporated into the GIS subsystem.

Satellite data processing involves several stages. The first stage is preliminary data processing that includes image geometrical correction and transformation to desirable map projections, georeference, as well as radiometric correction and preliminary processing of multiband images to increase their quality. At the second stage, normalized images are used to carry out thematic processing of remote sensing data. This is done by pattern classification and recognition methods. The third stage of remote sensing information processing involves the resulting data expert estimation.

The multi-band satellite and DEM-composite images were classified separately using the most widespread thematic standard classification procedure (ISODATA) (Tou and Gonzalez 1974; Richards 1986) that proved to be effective.

\section{RESULTS AND DISCUSSION}

\section{Classification of forest vegetation and forest site conditions}

Using the above principles and methods, we developed classification of site conditions taking into account site topology and the associated vegetation types for the study area. To do this, we used Digital Elevation Model (SRTM-3-DEM) (http://www2.jpl.nasa. gov/srtm/russia.htm) to build topological transects that crossed the study area and analyzed these transects using the thematic and general geographic maps contained in the GIS database, literature information, and ground observation data.

DEM-based topographic profiles showing geomorphological characteristics of the area were built (Fig.1).

\section{Fig. 1.: DEM-based topographic profiles (1-3)}

Geomorphological complexes of forest site conditions (I-III):

I. Low flat alluvial-accumulative plain (floodplains and low river terraces, 120-270 m a.s.l.)

supporting spruce stands on loamy soils in the lower parts of slopes lining river valleys, waterlogged spruce stands on alluvial soils in river flood valleys and on low river terraces, and Scots pine stand on soils of light texture on soft slopes of river terraces.

II. Moderately and heavily dissected denudation and denudation-erosion elevated plains (270-400 m a.s.1.) underlain by terrigenous and volcanic-origin deposits supporting mixed larch-Scots pine and Scots pine-larch stands with small shrub-grass-feather moss ground vegetation.

III. Dissected middle-mountain plateaus containing hills and ridges (400-860 m a.s.1.) underlain by calcareous, terrigenous, and volcanic bed material with intrusions of traps, with slopes occupied by Scots pine-larch- and larch-Scots pine-small shrub-feather moss stands and flat sites covered by dark conifer stands with grasses and feather moss as ground vegetation. 

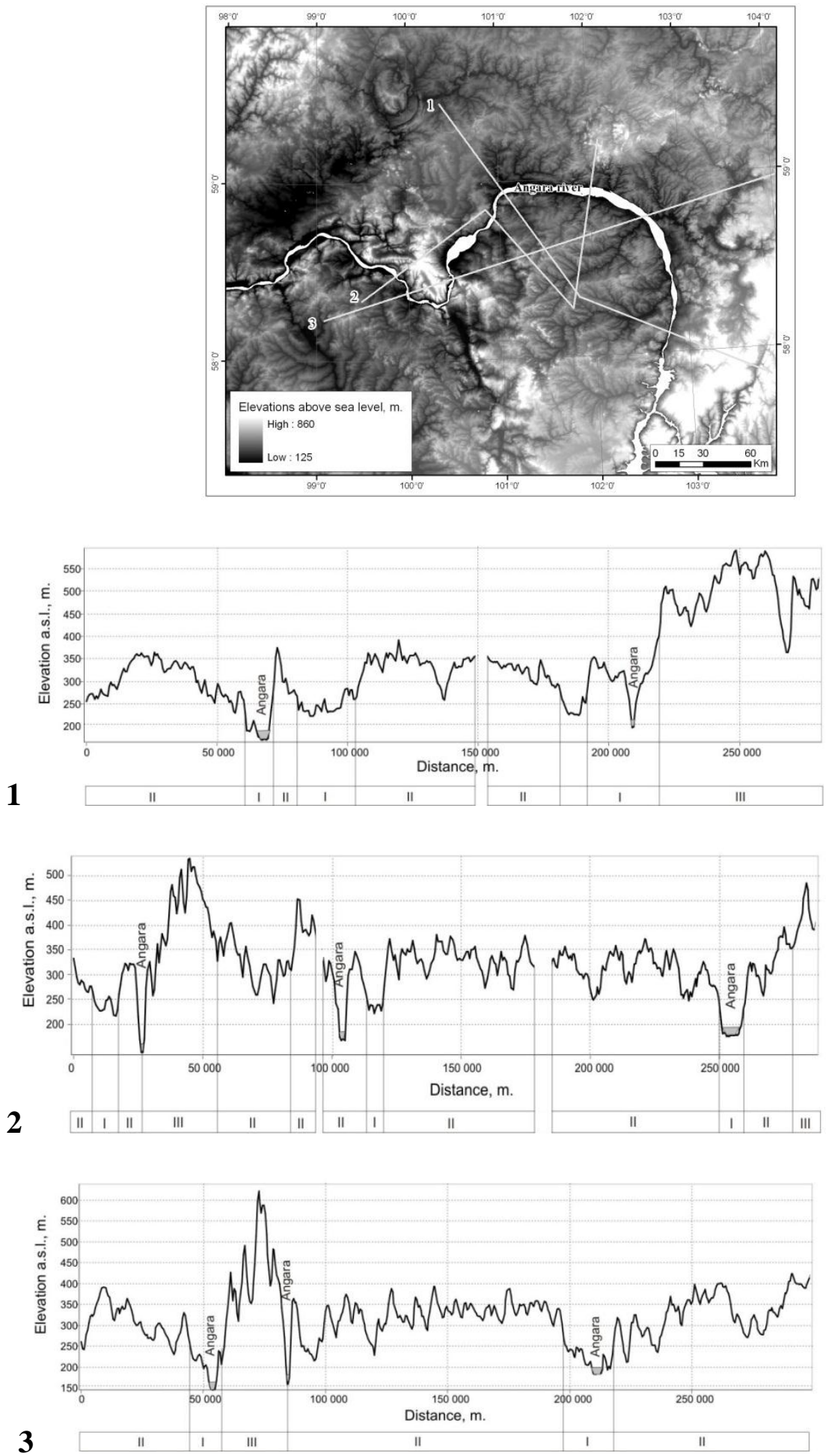
Using these profiles and landscape maps (Sochava 1977; Gudilin 1987), we analyzed geomorphological conditions of the area of interest and identified sites fairly similar in relief (i.e., in mesorelief form, range of elevations above sea level, and dissection of surface) that presumably correspond to different geomorphological complexes (GMC) of forest site conditions. Woody species composition of dominant native and secondary forest types were determined for each GMC for further more detailed classification of current forest communities.

Forest regeneration series typical for different forest site conditions were built for the plain and low-mountain parts of the area of interest using field, archive, and literature data. The regeneration series consist of forest age stages grouped by age class. The age stages are as follows: (a) initial regeneration stages (burned and logging sites); (b) young (up to 40 years old) deciduous stands; (c) mixed conifer-deciduous stands aging 40-80; (d) conifer stands 80- 120 years old approaching cutting age; and (e) mature and old conifer stand over 120 years of age.

Our work resulted in development of a joint classification of forest vegetation and site conditions, which formed the key of a forest regeneration map and reflect forest regeneration trends in various environmental conditions (see Appendix).

\section{GIS-based mapping algorithm}

An algorithm for creating a forest regeneration map based on spatial analysis of Landsat ETM+ imagery, digital elevation model SRTM-3-DEM and ground data was developed and tested for a test site in Angara region using "Forests of Central Siberia" GIS. This computer mapping algorithm of forest regeneration series is based on automated methods of spatial data analysis combined with expert data estimates.

This algorithm included the following steps: selection and preprocessing of input data (satellite images and DEM); secondary DEM features calculation (DEM composite layers: dissection, slope, curvature); satellite and DEM-composite image unsupervised classification; initial information class analysis and identification; production of vegetation and site conditions raster layers; layer raster-to-vector conversion and polygonal generalization; overlay of vector layers, class combinations analysis, and production of new forest regeneration classes.

The first step included selection of Landsat TM/ETM images to cover the site of interest and preliminary analysis of quality. 5-4-3 Landsat TM/ETM bands RGB-composites were used for satellite image visual examination. The image dates were selected to cover the main part of the growing season in central Siberia (from June 15 to August 20).

A raster layer of elevations above sea level was formed for the area of interest using the available digital models (e.g., SRTM-3-DEM). Secondary DEM feature layers of slope (S), surface curvature (C) (Moore et al. 1991) and surface dissection (R) (Sedykh 1991) were generated in addition to elevations above sea level $(\mathrm{H})$. To simplify the following raster layer processing, H, C, S, and R values were rescaled to fall within a range of 0 to 255 . HR and HSC DEM-composites were used to classify site conditions of levels 1 and 2, respectively.

In effort to develop a map of site conditions, the landscape map (Gudilin 1977) was analyzed to reveal that the test area includes the following three major landscape groups: low plains, elevated plains, and low mountains. Then, an unsupervised classification of the 
two-layer image (elevation above sea level and surface dissection) was carried out. The classes obtained were analyzed and identified by an expert using the landscape map and topographic profiles. These classes were identified as geomorphological complexes of site conditions (Table 1).

\section{Table 1: Land cover classes identification}

All statistical values were calculated using cells in the input raster that belong to the same class.

\begin{tabular}{|c|c|c|c|c|c|c|c|c|c|}
\hline \multicolumn{4}{|c|}{$\begin{array}{l}\text { Geomorphological complexes of } \\
\text { forest site conditions (level 1) }\end{array}$} & \multicolumn{5}{|c|}{$\begin{array}{l}\text { Combinations of forest site conditions types } \\
\text { (level 2) }\end{array}$} & \multirow{2}{*}{$\begin{array}{l}\text { Regenera- } \\
\text { tion series } \\
\text { and their } \\
\text { combina- } \\
\text { tions }\end{array}$} \\
\hline $\begin{array}{c}\text { Elevation } \\
\text { a.s.l. } \\
\text { interval, m }\end{array}$ & $\begin{array}{c}\text { Surface } \\
\text { dissection } \\
\text { interval }(\mathrm{R})\end{array}$ & $\begin{array}{c}\text { Mean } \\
\mathrm{R}\end{array}$ & $\begin{array}{l}\text { STD } \\
\mathrm{R}\end{array}$ & $\begin{array}{c}\text { Elevation } \\
\text { a. s. l., } \\
\text { interval, m }\end{array}$ & $\begin{array}{l}\text { Mean } \\
\text { elevation } \\
\text { a.s.l., } \mathrm{m}\end{array}$ & $\begin{array}{l}\text { STD } \\
\text { elevation } \\
\text { a.s.l., } \mathrm{m}\end{array}$ & $\begin{array}{l}\text { Mean } \\
\text { slope, } \\
\text { degr. }\end{array}$ & $\begin{array}{l}\text { STD } \\
\text { slope, } \\
\text { degr. }\end{array}$ & \\
\hline I. $122-270$ & $8.86-41.42$ & 20.77 & 5.61 & $\begin{array}{l}125-298 \\
159-291 \\
123-326\end{array}$ & $\begin{array}{l}175.00 \\
218.36 \\
231.04\end{array}$ & $\begin{array}{l}16.40 \\
15.41 \\
26.58\end{array}$ & $\begin{array}{l}0.92 \\
2.37 \\
5.53\end{array}$ & $\begin{array}{l}1.61 \\
1.93 \\
2.65\end{array}$ & $\begin{array}{l}9,10 \\
4+9,10 \\
4,5+9\end{array}$ \\
\hline II. 271-397 & $15.09-42.81$ & 22.96 & 4.20 & $\begin{array}{l}189-345 \\
186-368 \\
242-388 \\
\end{array}$ & $\begin{array}{l}264.67 \\
290.10 \\
311.64 \\
\end{array}$ & $\begin{array}{l}13.90 \\
20.83 \\
15.59\end{array}$ & $\begin{array}{l}2.35 \\
4.59 \\
2.06\end{array}$ & $\begin{array}{l}1.52 \\
1.97 \\
1.26\end{array}$ & $\begin{array}{l}3 \\
6+9 \\
6+7\end{array}$ \\
\hline III. 398-860 & $17.89-45.78$ & 31.30 & 6.26 & $\begin{array}{l}127-627 \\
257-497 \\
404-603 \\
481-763\end{array}$ & $\begin{array}{l}334.46 \\
367.52 \\
499.32 \\
586.10 \\
\end{array}$ & $\begin{array}{l}66.72 \\
33.49 \\
23.01 \\
45.82\end{array}$ & $\begin{array}{l}8.45 \\
3.16 \\
3.97 \\
7.19 \\
\end{array}$ & $\begin{array}{l}4.14 \\
1.77 \\
2.33 \\
3.15 \\
\end{array}$ & $\begin{array}{l}8 \\
2 \\
1 \\
11 \\
\end{array}$ \\
\hline
\end{tabular}

Geomorphological complex of site conditions is a high unit of site conditions classification. It covers sites similar in mesorelief forms, elevation range, and surface dissection and is characterized by certain climate, soils and set of forest regeneration series. It is the layer of level 1 site conditions map.

Then the multi-band satellite and three-layer DEM-composite (elevations above sea level, slope and surface curvature) images were classified separately by the ISODATA method. The elementary classes resulted from the DEM-composite image analysis were identified by an expert as a forest site conditions types and their combinations (flat interfluves, slopes of different steepness, river valleys and floodplains). These classes constituted the second level of the map of potential site conditions, which is required for correct identification of regeneration series (Table 1).

The elementary land cover classes obtained from remote sensing data classification were interpreted as age stages, non-forest sites being disregarded.

Three resulted raster layers (layers of two levels of site conditions and forest regeneration stages) were converted into polygonal vector layers. Then they were intersected to create a map of vegetation regeneration series (Fig.2.) using the joint classification of forest vegetation and site conditions (see Appendix). The resulting polygonal vector layers showed that distribution of forest regeneration series and stages covering a range of forest site conditions were obtained for the area of interest.

As is clear from the Classifier of Thematic Tasks of Natural Recourses and Environment Estimation Approached Based on Earth Remote Sensing Data (2008) (http://www.scanex.com/ru/classificator/index.html), Landsat images (30 m resolution) are used in development of the 1:100000-1:500000 thematic maps. The vegetation map obtained in this study is believed to be a 1:200000 map, since its production involved the use of the vector map generalization parameter (minimal mapped area $6 \mathrm{~mm}^{2}$ ). 


\section{Fig. 2: Fragments of two layers of the study area forest dynamics map.}

A-forest type level (see Appendix for detailed description of forest types 1-11). B-stand type (age stage) level.

A. The forest regeneration series and their combinations:

1. Series 1. 2. Series 3. 3. Series 4 in combination with series 9. 4. Series 4 in combination with series 9, 10. 5. Series 4 in combination with series 5 and 9. 6. Series 7. 7. Series 6 in combination with series 7. 8. Series 6 in combination with series 9. 9. Series 9 in combination with series 10. 10. Series 8.11. Series 11.

B. Forest regeneration stages:

1- initial regeneration stages on burned and logging sites; 2-young (up to 40 years old) deciduous stands; 3-mixed conifer-deciduous stands aging 40-80; 4-conifer stands 80- 120 years old approaching cutting age; 5- mature and old conifer stand over 120 years of age.

$\mathbf{A}$

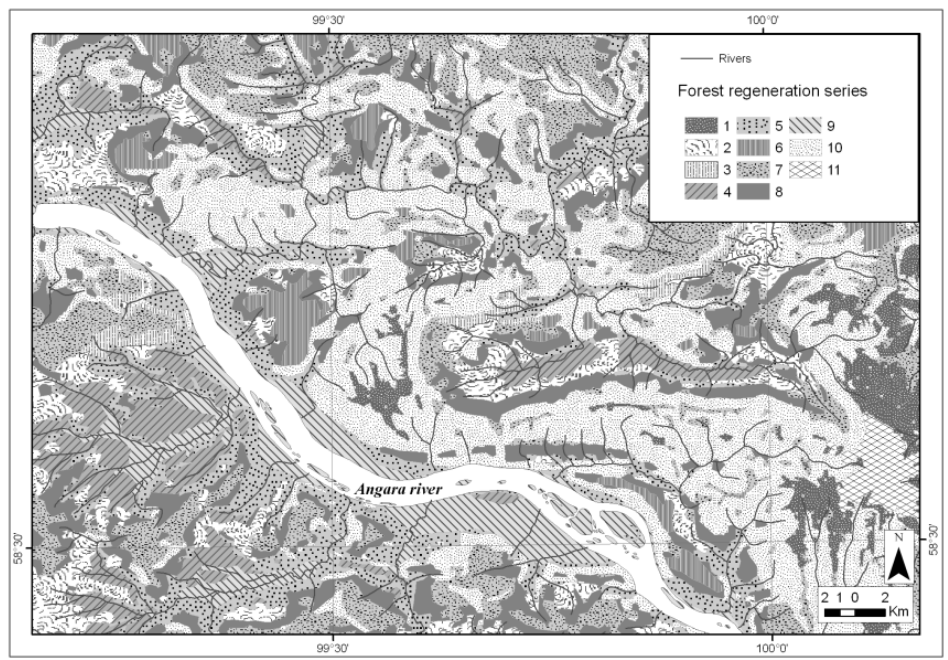

B

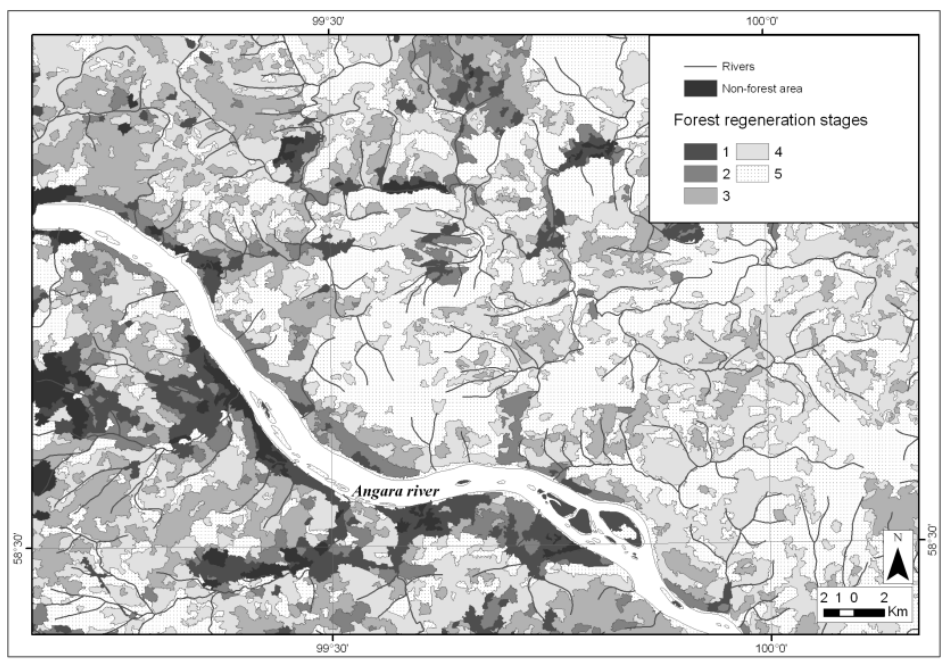


This map consists of several layers, and each layer shows distribution of one of the units of the topogenetic vegetation classification. Forest regeneration series and their combinations are shown in the map (Fig.2). The map key reflects two classification levels regeneration series developed using the age stages for different site conditions (level A) and forest age stages (level B).

Level A is forest types (i.e. regeneration series). A forest type is characterized by a certain ratio between dominant and co-dominant woody species throughout all succession phases.

Level B is stand types (or age stages). These are even-aged parts of forest stands (within a range of 20 years). This level shows stand age structure in a given area.

The map of vegetation dynamics based on joint classification of site conditions and forest vegetation reflects the relative correspondence of forest types to certain site types and allows us to identify forest regeneration trends under various site conditions.

These maps incorporated in the GIS database allow us to estimate forest regeneration with an account of spatial differences in ecological conditions. Information about site conditions and characteristics of forest type for each contour of the map are provided in GIS ecological database. The information on stand types (age stages) forming each forest type includes the following basic parameters: species composition, age, productivity, growing stock volume, and ground vegetation diversity indexes. The parameters of the site conditions supporting each forest type include relief elements, soils, and bedrock. These parameters are also provided in the database.

The maps obtained show current vegetation cover state. As the map key is based on the topogenetic classification that shows site-specific forest vegetation development, these maps also enable to predict dynamics of forest regeneration in different site conditions.

\section{CONCLUSION}

The topogenetic classification of forest communities was proved to be most suitable for mapping and estimation of forest ecosystem diversity. It considers the vegetation diversity as a system of forest regeneration phases under various site conditions.

The methodology developed in this study is a step-by-step algorithm to identify forest cover units similar in the features set. The human factor involvement in thematic mapping was minimized by using methods of automated DEM and satellite imagery classification and GIS-based spatial analysis procedures. Combining automated class discrimination methods with expert estimates allowed us to identify forest regeneration series (the basic units of the topogenetic forest cover classification) and vegetation age stages. These are the two major forest cover characteristics, which, although invisible in satellite images, are thematic mapping targets.

The maps incorporated in the GIS database reflect forest regeneration dynamics in time and space. They are actually spatial vegetation models that show ecosystem diversity. The results obtained can be useful for developing principles of sustainable forest management, monitoring forest landscape diversity and improving methods of forest inventory and mapping. 


\section{ACKNOWLEDGEMENT}

This work was supported by Russian Fundamental Research Foundation Grants 10-0500941-a.

\section{REFERENCES}

Classifier of thematic tasks of natural recourses and environment estimation approached based on earth remote sensing data. 2008. Edition 7. Irkutsk. http://www.scanex.com/ru/ classificator/index.html

Cherkashin, V.P., Korets, M.A. (2004). The results of "Forests of Central Siberia" GIS development. In: Vaganov E.A. (Ed.): Proceedings of the conference "Forest Structural and Functional Dynamics”. pp.383-387. Krasnoyarsk,

Ermakov, N.B., Polyakova, M.A., Popov, D.Yu., \& Golomovzin, V.V. (2007). Modeling of spatial organization of mountain vegetation based on remote sensing data and a digital elevation model. Computation Technologies, 12. Special Issue 2. Application of Information Technologies in Biological Investigations, An integrated interdisciplinary project of the Siberian Branch of Russian Academy, pp. 42-59.

Filroseh, E.M. (1983). An outline of a genetic classification of southern Ural forest types. In: Zubareva, R.S., Filroseh E.M., (Eds.): Ecogeographic and genetic principles of forest investigation. pp. 53-59, Sverdlovsk, Russia.

Golgofskaya, K.Yu. (1983). Using a topogenetic approach for identifying mountain forest types and zones. In: Zubareva, R.S., Filroseh E.M., (Eds.): Ecogeographic and genetic principles of forest investigation. pp.60-63. Sverdlovsk, Russia.

Gudilin, I.S. (1987). The USSR Landscape Map (1:2 500000). Moscow.

Ivashkevich, B.A. (1933). Forests of the Russian Far East and their future use. Khabarovsk: The Russian Far East OGIZ.

Kharuk, V.I., Im, S.T, Ranson, K.J., \& San, G. (2005). Using high-resolution space imagery to analyze the forest-tundra ecotone temporal dynamics. Earth Investigation from Space, 6: 46-55.

Kireyev, D.M. (1963). Experience gained in forest type recognition in aerial images. Methods of Forest Recognition in Aerial Images. USSR Academy of Sciences, MoscowLeningrad.

Kirsanov, V.A., Smolonogov, E.P. (1967). Principles of classification of forest environments and forest types in Lozva Region of Ural Mountains. Geographical Issues of Mountain Forest Management and Science. Chita, Russia. pp.19-22.

Konovalova, T.I., Bessolitsina, E.P. \& Vladimirov, E.N. (2005). Landscape Interpretation and Mapping. Nauka Publications, Novosibirsk.

Kolesnikov, B.P. (1956). Siberian pine forests of the Russian Far East. MoscowLeningrad: Nauka Press.

Krauklis, A.A., Medvedev, Yu.O. (1966). Vegetation in a series of fine-scale maps showing environmental dynamics. In: Sochava V.B., Isachenko T.I. (Eds.): Geobotanical Mapping. pp. 26-35. Nauka Publications, Moscow-Leningrad,

Merekalova, K.A. (2006). Identifying ecosystems of similar component interaction types. Abstracts of an international conference on landscape design: general principles, methodology, and technology, Moscow University, pp. 199-203. 
Mkrtchan, A.S. (2006). Automated identification of landscape units using GIS-based relief classification. Abstracts of an international conference on landscape design: general principles, methodology, and technology, Moscow University, pp 203-208.

Moore, I. D., Grayson, R. B., \& Landson, A. R. (1991). Digital Terrain Modelling: a Review of Hydrological, Geomorphological, and Biological Applications. Hydrological Processes, 1 (5):3-30.

Pfister, R.D., Kovalchik, B.L., Arno S.F., \& Presby, R.C. (1977). Forest habitat types of Montana. USDA For. Serv. Gen. Tech. Report INT, V.34. 174 p.

Popov, L.V. (1982). Southern Taiga Forests of Central Siberia. Irkutsk University Publications, Irkutsk.

Puzachenko, Yu.G., Koroshev, A.V. \& Aleshchenko, G.M. (2003). Landscape analysis using a space image. Earth Investigation from Space, 3: 63-71.

Richards, J.A. (1986). Remote Sensing Digital Image Analysis. Springer, Berlin.

Rosenberg, V.A., Manko \& Yu.I. (1983). Ecological and geographical principles of forest management in dark conifer forests of north-western Pacific. . In: Zubareva, R.S., Filroseh E.M., (Eds.): Ecogeographic and genetic principles of forest investigation. pp. 48-52. Sverdlovsk, Russia.

Ryzhkova, V.A. Korets, M.A. \& Cherkashin, V.P. (2004). GIS-based assessment of the current forest ecosystem condition, regeneration dynamics, and biodiversity. Siberian Ecological Journal, 5 : 715-724.

Sedykh, V.N. (1991). Aerospace monitoring of forest cover. Nauka Publications, Novosibirsk.

Smolonogov, E.P. (1970). Stand age dynamics and selective logging in broad-leaved/dark conifer forests. Forest Dynamics and Structure in the Urals. Sverdlovsk, Russia. pp.117-135.

Smolonogov, E.P. (1998). The basic principles of a genetic approach to developing forest type maps. Ecology 4: 256-261.

Sochava, V.B. (1977). Landscapes of Southeastern Siberia (1:1 500000 map). Moscow.

SRTM-3-DEM (Shuttle Radar Topography Mission Digital Elevation Model). Available from http://www2.jpl.nasa.gov/srtm/russia.htm

Sukachev, V.N. (1972). Selected Works. Fundamentals of Forest Typology and Biogeocenology, Vol. 1. Nauka Publications, Leningrad.

Sysuev, V.V. (2006). Landscape design and forest use improvement. Abstracts of an international conference on landscape design: general principles, methodology, and technology, Moscow University, pp 81-116.

Sysuev, V.V., Shary, P.A. (2000). Identifying types of site conditions to inventory forests based on a site method. Forest Science, 5: 10-19.

Tou, J. T., Gonzalez, R. C. (1974). Pattern Recognition Principles. Reading, Massachusetts: Addison-Wesley Publishing Company.

Walker, D.A. (2000). Hierarchical subdivision of Arctic tundra based on vegetation response to climate, parent material and topography. Global Change Biology, 6 (1): 19-34.

Zubareva, R.S., Smolonogov, E.P. \& Filroseh, E.M. (1983). Fundamentals of topogenetic classification of forest types and its prospects. In: Zubareva, R.S., Filroseh E.M., (Eds.): Ecogeographic and genetic principles of forest investigation. pp. 37-42. Sverdlovsk, Russia. 


\section{APPENDIX}

The forest regeneration series:

1. Dark coniferous taiga forests on loamy soils of well-drained watersheds and slopes (450$520 \mathrm{~m}$ a.s.l.). The major communities: mixed fir/spruce stands with ground vegetation constituted by feather moss and herbs. Secondary communities: birch stands with ground vegetation constituted by various herbs or feather moss and herbs. Site Class III.

2. Dark coniferous taiga forests on loamy soils and clay found in flat watersheds and on moist slopes (400-450 m a.s.1.). Major communities: mixed Siberian pine/fir stands with feather moss as the ground vegetation. Secondary communities: mixed aspen/birch stands with tall herb/tall grasses, or various herbs/tall herbs ground vegetation. Site Class III.

3. Scots pine stands on loams in low flat watersheds and on soft slopes (250-300 m a.s.1.). Major communities: Scots pine stands with minor components of larch and dark-needled conifers with ground vegetation constituted by feather moss mixed with herbs. Secondary communities: mixed birch/aspen stands with herbaceous or mixed herb/feather moss ground vegetation. Site Class III.

4. Scots pine stand on soils of light texture on soft slopes of river terraces (170-300 m a.s.1.). Major communities: Scots pine stands with ground vegetation constituted by red whortleberry mixed with herbs or feather moss. Secondary communities: mixed birch/Scots pine stands with only herbs or feather moss mixed with herbs as ground vegetation. Site Class III.

5. Scots pine stands on sandy soils in watersheds and on high terraces of big rivers (200-250 $\mathrm{m}$ a.s.1.). Major communities: Scots pine stands with ground vegetation constituted by whortleberry mixed with herbs, or pure whortleberry, or lichen mixed with whortleberry; these stands regenerate without woody species conversion, with the growing conditions promoting young Scots pine stands with pure dead needle litter, or dead needle litter/red whortleberry, or lichen/red whortleberry ground vegetation cover. Site Class IV.

6. Mixed Scots pine/larch stands on loamy and clay calcareous soils on soft and moderately steep slopes between rivers (300-350 m a.s.l.). Major communities: mixed Scots pine/larch stands with ground vegetation constituted by feather moss mixed with herbs, or pure feather moss. Secondary communities: birch stands or mixed birch/aspen stands with only herbs, or tall herbs mixed with tall grasses, or various herbs mixed with tall grasses in the ground vegetation cover. Site classes II and III.

7. Mixed Scots pine/larch stands on loamy and clay soils in the upper parts of slopes and on hill tops found in dome-shaped and hilly watersheds (350-400 m a.s.1.). Major communities: mixed Scots pine/larch stands with feather moss and small shrubs in the ground vegetation cover. Secondary communities: birch stands with tall grass/herb, herb/feather moss, or herb/small shrub ground vegetation. Site Class IV.

8. Mixed larch/Scots pine stands on loams and clay on moderately and highly steep slopes between rivers (300-500 $\mathrm{m}$ a.s.1.). Major communities: mixed larch/Scots pine stands with ground vegetation constituted by feather moss mixed with either herbs or small shrubs. Secondary communities: birch stands with only tall herbs or tall herbs mixed with tall grasses in the ground vegetation cover. Site Class IV.

9. Spruce stands on loamy soils in the lower parts of slopes lining river valleys. Major communities: spruce stands with a minor larch component with ground vegetation constituted by feather moss mixed with herbs. Secondary communities: birch stands with ground vegetation represented by tall herbs or tall herbs mixed with tall grasses. Site Class IV.

10. Waterlogged spruce stands on alluvial soils in river flood valleys and on low river terraces. Major communities: spruce stands with ground vegetation dominated by grasses common in marsh. Secondary communities: birch stands with similar ground vegetation. Site Class IV.

11. Siberian Pine stands on loamy soils with crushed stone in highly elevated watersheds (>560 m a.s.l.). Major communities: mixed Siberian pine/fir/spruce stands with mixed feather moss/small herb/small shrub ground vegetation. Secondary communities: birch stands with ground vegetation represented by tall grasses mixed with herbs, or herbs mixed with feather moss. Site Class IV. 